\title{
Relation of Transverse Air Permeability with Physical Properties in Different Compositions of Sugarcane Bagasse Particleboards
}

\author{
Lina Bufalino*, Lourival Marin Mendes, Gustavo Henrique Denzin Tonoli, \\ Mário Vanoli Scatolino, José Reinaldo Moreira da Silva, Fábio Akira Mori \\ Departamento de Ciências Florestais - DCF, Universidade Federal de Lavras - UFLA, \\ CP 3037, CEP 37200-000, Lavras, MG, Brasil
}

Received: December 16, 2011; Revised: August 23, 2012

\begin{abstract}
Studies concerning the production of particleboards with sugarcane bagasse as an alternative fibrous material have been carried out as an attempt to provide a sustainable and viable destination for this residue. This work aimed to evaluate the influence of several processing variables related to the microstructure of sugarcane bagasse particleboards (mat type, adhesive type and adhesive content) on their permeability and water sorption properties. Air permeability data was collected by the rotameter method. Superficial air permeability $(\mathrm{kg})$, Darcian constant $\left(k_{l}\right)$ and non-Darcian constant $\left(k_{2}\right)$ were measured. $\mathrm{kg}$ was related to sorption behavior of the particleboards. 1-layer particleboards presented significantly higher kg values than the 3-layer particleboards. In general, adhesive type, position and content did not influence $\mathrm{kg}$ of particleboards. However, these processing variables influenced interactions between fluid and material and tortuosity of the porous media. Particleboards produced with urea-formaldehyde with high kg presented higher water absorption and thickness swelling after 24 hours. Such relations were not observed in particleboards produced with melamine-urea-formaldehyde.
\end{abstract}

Keywords: air permeability, sugarcane bagasse, water absorption, thickness swelling, mat

\section{Introduction}

The large amount of wood consumption could mean a high worldwide deforestation rate that can cause environmental impacts. This context leads to introduction of new composites with enhanced properties, such as particleboards, oriented strand boards, plywoods, and hardboards. These products are currently known as suitable engineering materials for building and construction ${ }^{1-3}$.

Non-wood lignocellulosic biomass such as grass, straw and agricultural residues present great potential for panels manufacturing, including particleboards $\mathrm{s}^{4,3}$. Sugarcane bagasse is considered among agricultural residues the most promising substitute for wood in particleboard production due to its anatomical and chemical characteristics ${ }^{5}$. This lignocellulosic residue is produced in large amounts by sugar crushing and extraction, hence its disposal on sugar industries may cause economic and environmental problems ${ }^{6-8}$. Transforming this waste in bagasse particleboards may contribute to sustainability and provide an interesting solution for value aggregation ${ }^{9}$.

Several researchers ${ }^{5-7,9-12}$ have been carrying out concerning production of particleboards and fiberboards with sugarcane bagasse as an alternative raw material. Some of them reported that sugarcane particleboards present high water absorption and poor dimensional stability, which may be influenced by the raw material and processing variables

*e-mail: linabufalino@yahoo.com.br such as adhesive type and content ${ }^{9,11}$. Panels made from lignocellulosic residues adsorb or desorb moisture according to the changes in environmental temperature and humidity. This dimensional instability may interfere in the quality of the product in service ${ }^{13}$.

Permeability describes how easy fluids are transported throughout the structure of a porous solid material under pressure gradient ${ }^{14}$. This physical property is extremely important to the development of durable materials, since it can be associated with their structural properties and resistance to penetration of environmental degradation agents ${ }^{15}$. Permeability strongly depends on the microstructure of materials, which is affected by processing variables ${ }^{16}$. Some researchers have studied the permeability of particleboard mats with the aim to analyze the rate of convective heat transference to the panel core for adhesive curing during pressing ${ }^{17-20}$.

To our knowledge, there is a lack of information in the literature about the influence of air permeability on water absorption and thickness swelling of post-pressed particleboards. For this reason, this work aimed to evaluate the influence of several processing variables related to the microstructure of particleboards (mat type, adhesive type, adhesive position and adhesive content) on the permeability and water resistance properties of laboratorial and commercial sugarcane particleboards. 


\section{Material and Methods}

\subsection{Raw materials}

Sugarcane bagasse obtained from Monte Alegre alcohol refinery (Minas Gerais state, Brazil), urea-formaldehyde (UF - solid content of 52 wt. (\%)) and melamine-urea-formaldehyde (MUF - solid content of 54 wt. (\%)) adhesives were used for manufacturing the laboratorial particleboards. The wax emulsion was applied at $1 \mathrm{wt}$. (\%) as water repellent during particleboard production.

\subsection{Particleboard production}

Sliver particles were produced in a hammer mill using sieves with openings of 6.14 and $1.72 \mathrm{~mm}$ for core and surface layers of the panels, respectively. The material was dried to 3 wt. (\%) moisture content at $60 \pm 5{ }^{\circ} \mathrm{C}$ before particleboard manufacturing. The effects of mat type (1-layer and 3-layer), adhesive types (UF, MUF, UF/MUF/UF mixture and MUF/UF/MUF mixture) and adhesive contents ( 9 and 12 wt. (\%)) for both surface and middle layers were evaluated. In addition, commercial sugarcane bagasse particleboards produced in China were used for comparison. The experimental design for the particleboards is summarized in Table 1.

The boards were manufactured similarly to the procedures described by Barros Filho et al. ${ }^{9}$. Particles were put in a blender where the adhesives and wax emulsion were applied by an air spray gun. The material was molded in a mat-forming box $(48 \times 48 \mathrm{~cm})$ and a manual press machine was used to perform a pre-pressing at $0.78 \mathrm{MPa}$. The mat was then submitted to hydraulic press and the boards were made by using $8 \mathrm{~min}$ of pressing under $3.92 \mathrm{MPa}$ and a temperature of $150{ }^{\circ} \mathrm{C}$. 3-layer particleboards were produced with smaller particles on the surface and larger particles in the core. The proportion was 20/60/20\% for surface/core/surface of the particleboard mass. 1-layer particleboards were produced with larger particles. The target apparent density of $0.700 \mathrm{~g} \mathrm{.cm}^{-3}$ and nominal thickness of $15 \mathrm{~mm}$ were held constant for all particleboards. Four laboratorial particleboards were produced for each mix design.
Four commercial particleboards were reduced to the final nominal dimension of $48 \times 48 \mathrm{~cm}$. They presented the same thickness of laboratorial particleboards.

All the boards were conditioned at $20 \pm 2{ }^{\circ} \mathrm{C}$ and $60 \pm 3 \%$ RH during about 25 days, leading to a final moisture content of about $10 \%$.

\subsection{Air permeability test}

Figure 1 depicts the sampling scheme for obtainment of specimens for the permeability test. Four $2.0 \times 2.0 \times 1.5 \mathrm{~cm}$ specimens were extracted from each particleboard.

Since air permeability was evaluated in transversal direction, the specimen's edges, which were not under evaluation, were sealed with structural epoxy based fluid adhesive previously prepared by the mixture of A (epoxy resin) and B components (polyamine-amid) at a proportion of 1:1.5. After 7 days of epoxy curing, the material was once more stabilized in an acclimatizing room $\left(20 \pm 2{ }^{\circ} \mathrm{C}\right.$ and $65 \pm 3 \% \mathrm{RH})$. The specimen's edges were then covered using a $2.5 \mathrm{~cm}$-long piece of rubber tube with diameter of $2.5 \mathrm{~cm}$.

The air permeability of each sample was measured according to the rotameter method, which uses atmospheric air as a fluid. The transverse air permeability at room temperature $\left(25-30{ }^{\circ} \mathrm{C}\right)$ of each sample was measured in an apparatus adapted from Silva et al. ${ }^{21}$ and Siau ${ }^{14}$,

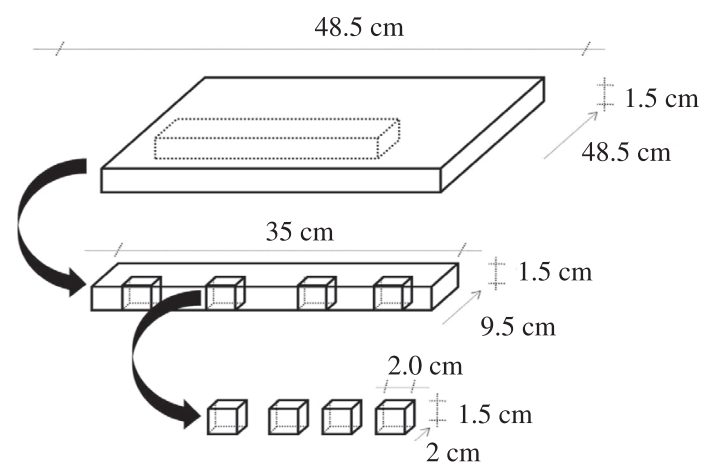

Figure 1. Sampling scheme for obtainment of the specimens for air permeability tests.

Table 1. Descriptors of the particleboards.

\begin{tabular}{|c|c|c|c|}
\hline \multirow{2}{*}{ Particleboards } & \multicolumn{2}{|c|}{ Adhesive } & \multirow{2}{*}{ Mat } \\
\hline & Type & Content (wt. (\%)) & \\
\hline UF9-1L & $\mathrm{UF}^{1}$ & \multirow{2}{*}{9} & \multirow{2}{*}{ 1-layer } \\
\hline MUF9-1L & MUF $^{2}$ & & \\
\hline UF9-3L & UF & \multirow{4}{*}{9} & \multirow{9}{*}{ 3-layer } \\
\hline MUF9-3L & MUF & & \\
\hline MUF/UF9-3L & MUF/UF/MUF & & \\
\hline UF/MUF9-3L & UF/MUF/UF & & \\
\hline UF12/9-3L & $\mathrm{UF}$ & \multirow{2}{*}{$12 \mathrm{~S} / 9 \mathrm{C} / 12 \mathrm{~S}^{3}$} & \\
\hline MUF12/9-3L & MUF & & \\
\hline UF9/12-3L & UF & \multirow{2}{*}{$9 \mathrm{~S} / 12 \mathrm{C} / 9 \mathrm{~S}$} & \\
\hline MUF9/12-3L & MUF & & \\
\hline \multicolumn{3}{|c|}{ Commercial sugarcane particleboards } & \\
\hline
\end{tabular}

${ }^{1}$ UF: urea-formaldehyde; ${ }^{2}$ MUF: melamine-urea-formaldehyde; ${ }^{3}$ S/C/S: surface/core/surface of 20/60/20\% of the particleboard mass. 
as presented in Figure 2. The apparatus consisted of two molded $0.02 \mathrm{~m}$ size PVC tubes, which allow fitting $2.0 \times 2.0 \times 1.5 \mathrm{~cm}$ rectangular specimens between them. The tubes were positioned on a wooden platform. One of them was connected to a vacuum pump and the other to three flowmeters which measure the following air flow ranges: $2.8 \times 10^{-6}$ to $27.8 \times 10^{-6} \mathrm{~m}^{3} / \mathrm{s}^{-1}, 2.8 \times 10^{-6}$ to $50 \times 10^{-6} \mathrm{~m}^{3} / \mathrm{s}^{-1}$ and $27.8 \times 10^{-6}$ to $305.5 \times 10^{-6} \mathrm{~m}^{3} / \mathrm{s}^{-1}$. The specimens were positioned between the PVC tubes and hot glue was applied to prevent air leakage. The air permeability was determined by turning on the vacuum pump to force the air flow through the specimen surfaces. The values obtained were the pressure made by the pump and the air flow rate given by each flowmeter.

The atmospheric pressure value used was 9239.3 Pa. The flow time considered for all specimens was 1 minute, due to the instantaneous stabilization of the flowmeters. The transverse superficial air permeability was determined by the Equation $1^{14}$ :

$k g=\frac{Q L P}{A \Delta P P m}$

where, $\mathrm{kg}$ is the superficial air permeability $\left(\mathrm{m}^{3} \cdot \mathrm{m}^{-1} \cdot \mathrm{s}^{-1} \cdot \mathrm{Pa}^{-1}\right)$, $Q$ is the volumetric flow range $\left(\mathrm{m}^{3} / \mathrm{s}^{-1}\right), L$ is the specimen thickness $(\mathrm{m}), P$ is the pressure during the flow rate measurement $(\mathrm{Pa}), A$ is the transversal area of the sample perpendicular to the flow direction $\left(\mathrm{m}^{2}\right), P m$ is the average pressure in the specimen $(\mathrm{Pa})$.

The experimental data was also adjusted in order to determine the permeability constants $k_{l}$ (Darcian constant) and $k_{2}$ (non-Darcian constant), which represent respectively the viscous effect of the shearing (friction and interactions between fluid and porous media) and the tortuosity of the porous media when the shearing velocity is high ${ }^{22}$. The higher the $k_{1}$ and $k_{2}$ values, the higher the permeability of the porous media. The permeability constants $k_{1}$ and $k_{2}$ were obtained by fitting the experimental data using Forchheimer's equation (Equation 2), expressed for flow of compressible fluids as showed by Inocentini et $\mathrm{al}^{23}$.
$\frac{P a t m^{2}-P^{2}}{2 P l}=\left(\frac{\mu}{K 1}\right) V S+\left(\frac{\rho}{K 1}\right) V S^{2}$

where $P_{a t m}$ and $P$ are the absolute inlet and outlet air pressures $\mathrm{Pa}$ ) which correspond to the atmospheric pressure and to the pressure during the flow rate measurement respectively; VS is the fluid velocity $\left(\mathrm{m} / \mathrm{s}^{-1}\right) ; L$ is the sample thickness $(\mathrm{m})$; $\mu$ is the fluid viscosity (air viscosity $\sim 1.8 \times 10^{-5} \mathrm{~Pa} . \mathrm{s}$ ); and $\rho$ is the fluid density (air density $\sim 1.08 \mathrm{~kg} \cdot \mathrm{m}^{-3}$ ).

\subsection{Tests for water absorption and thickness swelling}

The following physical properties were determined according to ASTM D1037-100 24 procedures: apparent density, water absorption and thickness swelling after 2 and 24 hours water immersion. Two specimens of each particleboard were used for physical tests.

\subsection{Data analysis}

The experimental design was entirely randomized. Eleven laboratorial particleboards, each one with four repetitions, were compared. The apparent density and $\mathrm{kg}$ data were submitted to the analysis of variance and the particleboards were compared by Scott-Knott test at $5 \%$ of significance. The permeability of 1-layer particleboards and 3-layer particleboards were compared by statistical contrast. The relation of $\mathrm{kg}$ with $k_{1}, k_{2}$ and dimensional stability of particleboards was also analyzed. The statistical software SISVAR was used to perform the analysis. The relation of $\mathrm{kg}$ with $k_{1}, k_{2}$ and dimensional stability of particleboards was analyzed.

\section{Results and Discussion}

The averages of measured apparent density in the laboratorial boards ranged from 0.63 to $0.66 \mathrm{~g} . \mathrm{cm}^{-3}$. Commercial sugarcane particleboards (C1) presented significantly higher apparent density $\left(0.71 \mathrm{~g} . \mathrm{cm}^{-3}\right)$ than laboratorial particleboards.

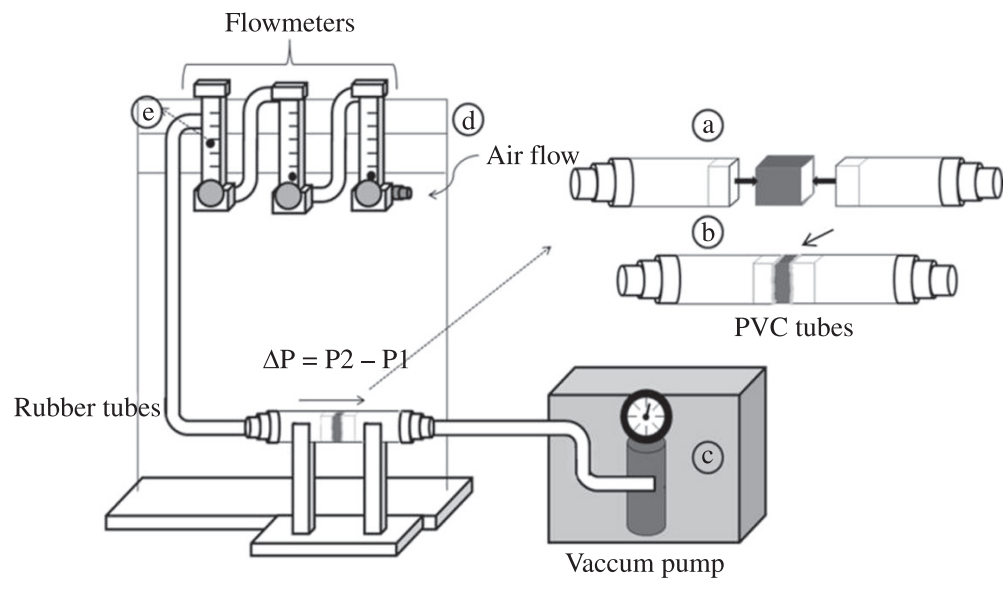

Figure 2. General view of the air permeability measurement apparatus. a) specimen positioned between the PVC tubes; b) hot glue application (arrow); c) vaccum pump; d) air flow entrance; and e) air flow measurement. 
The average values and standard deviation of superficial air permeability $(\mathrm{kg})$ of particleboards are given in Figure 3. The average values ranged from $0.1510^{-10}$ to $1.1610^{-10} \mathrm{~m}^{3} \cdot \mathrm{m}^{-1} \cdot \mathrm{s}^{-1} \cdot \mathrm{Pa}^{-1}$. Similar permeability measurements have been reported in the literature only for wood and cold pressed wood particle mats. Values ranging from $638010^{-10}$ and $84.110^{-10} \mathrm{~m}^{3} \cdot \mathrm{m}^{-1} \cdot \mathrm{s}^{-1} \cdot \mathrm{Pa}^{-1}$ were obtained for pine and eucalyptus woods, respectively ${ }^{21}$, through the same methodology applied in this work. Hata ${ }^{17}$ presented a permeability of $4.1110^{-8} \mathrm{~m}^{3} \cdot \mathrm{m}^{-1} \cdot \mathrm{s}^{-1}$.Pa for wood particleboards produced with density of $0.3 \mathrm{~g} \cdot \mathrm{cm}^{-1}$. Denser particleboards of 0.600 g.cm ${ }^{-3}$ were found completely impermeable. The lowest average permeability obtained by $\operatorname{Hood}^{25}$ for oriented strand boards (OSB) mats was $7.810^{-8} \mathrm{~m}^{3} \cdot \mathrm{m}^{-1} \cdot \mathrm{s}^{-1} \cdot \mathrm{Pa}$. The higher results may be attributed to the lack of density profile in the cold-pressed mats analyzed without adhesive.

Commercial sugarcane particleboards showed significantly ( $\mathrm{p}$-value $<0.05$ ) higher apparent density and lower kg than laboratorial particleboards. Particleboards with higher density had lower permeability because the resistance against air flow in the mats increases with the decrease of voids ${ }^{17,20}$.

1-layer particleboards presented superficial $\mathrm{kg}$ values statistically superior ( $\mathrm{p}$-value $<0.05$ ) to those from 3-layer particleboards, except for MUF/UF9-3L particleboards.
The contrast between the average values was significant and showed that the permeability of 1-layer particleboards is $0.04 \times 10^{-10} \mathrm{~m}^{3} \cdot \mathrm{m}^{-1} \cdot \mathrm{s}^{-1} \cdot \mathrm{Pa}^{-1}$ higher than the permeability of 3-layer particleboards. This is mainly attributed to the larger particles in the surface of 1-layer boards, which create larger voids among themselves when compared to the smaller particles used in 3-layer particleboards. Shang et al. ${ }^{26}$ found similar results for wood particle aggregates in which permeability increased with the increase of wood particle size from $3 \mathrm{~mm}$ to above $30 \mathrm{~mm}$.

Moreover, the surfaces composed by smaller particles presented a higher superficial area resulting in a longer air-flow pathway. This increases the lack of interconnection between the voids and consequently decreases the superficial permeability of the boards ${ }^{25}$. Since small particles comprise the surface of a 3-layer particleboard, a higher number of particles is required and an increased tortuosity of the porous media may occur, as discussed below.

In general, type, position and content of adhesives did not influence $\mathrm{kg}$ of the particleboards, since no significant differences ( $p$-value $>0.05$ ) were observed between permeability values of most 3-layer particleboards. However, these processing variables seemed to affect interactions between fluid (air), and material, besides tortuosity of the porous media. The relation between superficial air permeability $(\mathrm{kg})$ and $k_{1}$ and $k_{2}$ constants is shown in Figure 4.

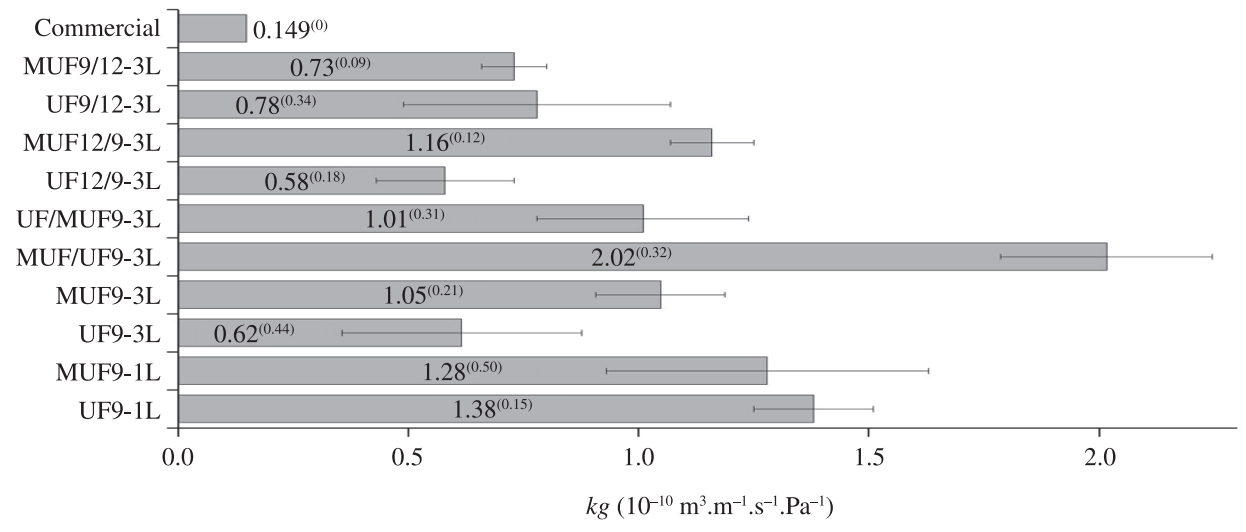

Figure 3. Average and standard deviation values of superficial air permeability $(\mathrm{kg})$.

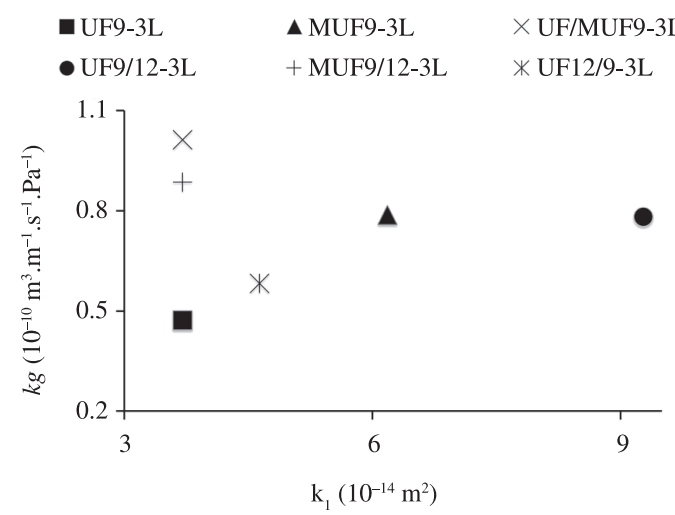

(a)

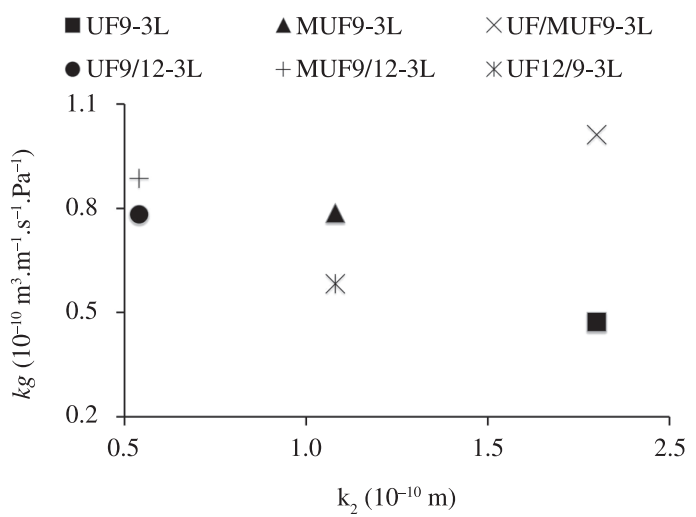

(b)

Figure 4. Relation between superficial air permeability, $k g$, and (a) Darcian constant, $k_{l}$, and (b) non-Darcian constant, $k_{2}$. 
Some of the permeability data of particleboards did not allow the adjustment of polynomial model, which is necessary for $k_{1}$ and $k_{2}$ constants calculation. Experimental measurements of permeability may be difficult to be implemented on materials with high porosity such as fiber-based boards ${ }^{16}$.

The decrease of $k_{1}$ indicates that friction and interactions between fluid and porous media increased. The increase of $k_{2}$ can signify the diminution of porous media tortuosity due to reduction of capillary forces ${ }^{15}$. For 3-layer and MUF/UF-3L particleboards it was not possible to calculate $k_{1}$ and $k_{2}$ constants due to the high permeability of these panels. The same occurred for commercial particleboards because only one sample presented permeability.

A comparison between UF9-3L and MUF9-3L indicates that the use of melamine-urea-formaldehyde increased superficial air permeability, decreased friction between air and particles, but increased tortuosity of the porous media. The results showed that a higher adhesive content (12\%) in the surface of the panels caused the decrease of superficial air permeability $(\mathrm{kg})$ due to increase in air friction, since UF12/9-3L particleboards presented lower $\mathrm{kg}$ and $k_{2}$ values in relation to UF9/12-3L particleboards. However, the lower $k_{1}$ was found for the formers. Particleboards made with two adhesive contents positioned in the different layers, UF9/12-3L and MUF9/12-3L, presented the same $k_{2}$ values and $\mathrm{kg}$, but a much higher $k_{1}$ value was observed for the particleboards made with urea-formaldehyde.

Many samples (20\%) were completely impermeable to air probably due to the lack of connection among voids in the porous structure of the particleboard samples. Only 3-layer and commercial particleboards provided completely impermeable specimens. Figure 5 illustrates possible pathways for air flow through the porous structure of 3-layer and 1-layer particleboards.

The impermeability of 3-layer particleboards may have happened due to three pathways of the air flow showed in Figure 5. The air flow reaches the whole surface of the specimen. Some voids allow only part of the air flow to enter into the sample and, once inside, part of the flow does not pass through the first layer, compounded by smaller particles, due to the lack of connection between the voids (red lines). Inside the core layer, part of the flow is limited by the smaller particles of second surface layer (green lines), where part of the flow is retained due to the lack of interconnection among the voids (yellow lines). In 1-layer particleboards, part of the air flow (blue lines) reaches the opposite surface and presents less tortuosity, increasing the values of $\mathrm{kg}$ for these samples.

Figure 6 shows the average values of water absorption after 2 hours and 24 hours of immersion in relation to $\mathrm{kg}$ values of the particleboards produced with urea-formaldehyde adhesive. The values ranged from 5 to $11 \%$ and from 24 to $42 \%$ for 2 hours and 24 hours of water immersion, respectively. The water absorption values observed in the present work are lower than those reported by Barros Filho et al. ${ }^{9}$ for similar particleboards produced with industrial sugarcane bagasse (WA_2h $=13.4 \%$ and WA_24h $=98.8 \%)$. However, the present results are similar to the average values found by Mendes et al. ${ }^{11}$ for panels produced with sugarcane bagasse and urea-formaldehyde adhesive (WA_2h = 5\% and WA_24h=42\%).

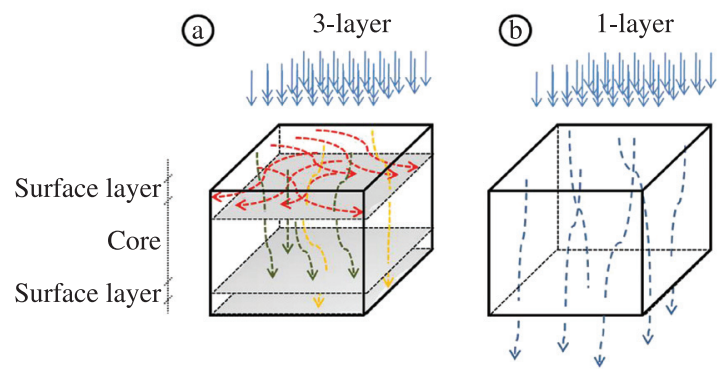

Figure 5. Illustrative scheme of possible pathways for air flow through the structure of a sample (with sides sealed) of particleboard. a) 3-layer particleboards; b) 1-layer particleboards. Red, green and yellow arrows indicate retained air flow, while blue arrows indicate continuous flow.

$\circ \mathrm{WA} \_2 \mathrm{~h} \cdot \mathrm{WA} \_24 \mathrm{~h}$

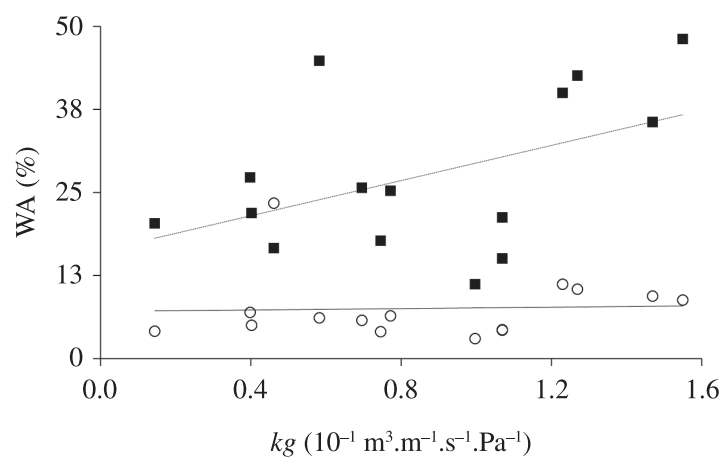

Figure 6. Superficial air permeability $(\mathrm{kg}) v s$. water absorption $(W A)$ after 2 hours and 24 hours for urea-formaldehyde particleboards.

After 2 hours of water immersion, no relation between water absorption and air permeability was observed. However, after 24 hours of water immersion, 1-layer particleboards produced with urea-formaldehyde, which presented higher $\mathrm{kg}$ values, also presented the highest water absorption value. A larger contact area provided by smaller particles in the surface should have allowed higher water absorption ${ }^{27}$, but the opposite was observed in this work due to the decrease of voids which diminished water absorption ${ }^{5}$. The lower permeability of 3-layer particleboards may be ascribed to a physical barrier to gas and water entrance created by the smaller particles, since they present smaller voids and increased contact area ${ }^{28}$.

Despite presenting the lowest air permeability among 3-layer particleboards produced with urea-formaldehyde, the UF9-3L particleboards presented higher water absorption after 24 hours water immersion than UF12/9-3L and MUF9/12-3L particleboards. Therefore, the lowest adhesive content (9\%) used in both surface and core of the particleboards presented higher influence on water absorption than permeability to fluids.

Figure 7 shows the average values of thickness swelling after 2 hours and 24 hours of water immersion in function of $\mathrm{kg}$ for particleboards produced with urea-formaldehyde adhesive. Thickness swelling of the laboratorial sugarcane particleboards produced with urea-formaldehyde ranged 
from $3 \%$ to $6 \%$ after 2 hours of water immersion and from $13 \%$ to $22 \%$ after 24 hours of immersion.

It was noticed in this research that all values of thickness swelling after 2 hours were lower than those found by Mendes et al. ${ }^{11}$ for panels produced with sugarcane bagasse and urea formaldehyde as adhesive. However, the authors found lower thickness swelling after 24 hours of water immersion (TS_2h $=7.8 \%$ and TS_24h $=11.8 \%$ ). Barros Filho et al. ${ }^{9}$ reported higher values for thickness swelling after 2 hours and 24 hours of water immersion than those found in the present work for similar particleboards $\left(\mathrm{TS} \_2 \mathrm{~h}=7.6 \%\right.$ and TS_24h $\left.=18.1 \%\right)$.

No relation between thickness swelling and air permeability after 2 hours of water immersion was observed. However, after 24 hours of water immersion, particleboard swelling increased with increases in air permeability. 1-layer particleboards produced with larger particles presented the highest values for both 2 hours and 24 hours water absorption. The reduction of the specific surface of the particles with the increase in particle size resulted in lower water absorption and thickness swelling ${ }^{29}$. On the other hand, the results showed that smaller particles in the surface might have decreased permeability and resulted in lower water absorption and thickness swelling. Large particles resulted in lower surface area available for bonding, weaker contact among the particles and higher voids in the microstructure of the particleboards. The same could be observed in the present work, which may indicate that not all large particles were well bonded by the adhesive, resulting in higher thickness swelling ${ }^{30}$.

Considering the adhesive content, the UF9-3L particleboards (urea-formaldehyde at $9 \%$ ) presented the highest water absorption and thickness swelling among 3-layer particleboards. UF12/9-3L particleboards presented lower thickness swelling than UF9/12-3L particleboards, which were produced with urea formaldehyde at $12 \%$ and $9 \%$, respectively. In addition, UF9/12-3L particleboards presented higher $\mathrm{kg}$.

Figures 8 and 9 showed average values of water absorption and thickness swelling (after 2 hours and 24 hours
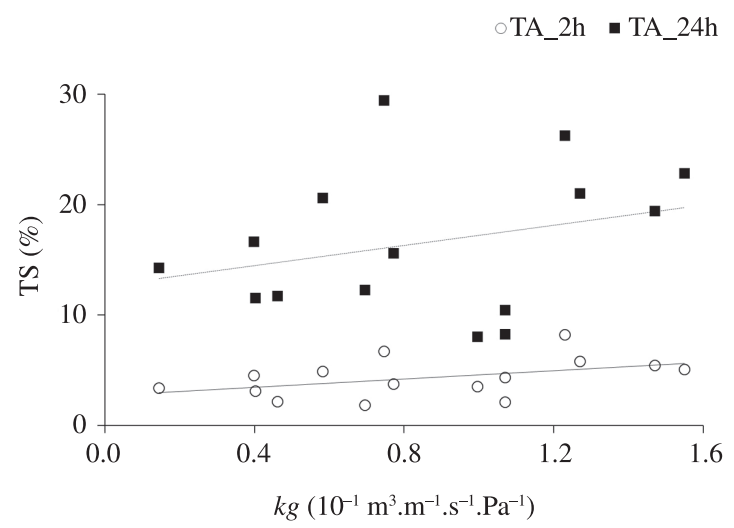

Figure 7. Superficial air permeability $(k g) v s$. thickness swelling (TS) after 2 hours and 24 hours for urea-formaldehyde particleboards. of water immersion), respectively, in function of $\mathrm{kg}$ for particleboards produced with melamine-urea-formaldehyde adhesive. Water absorption values after 2 hours and 24 hours of immersion for sugarcane particleboards produced with melamine-urea-formaldehyde ranged from 5 to $8 \%$ and from 21 to $38 \%$, respectively. Thickness swelling values varied from 2 to $3 \%$ after 2 hours and from 10 to $12 \%$ after 24 hours.

Average values of water absorption and thickness swelling for panels produced with melamine-urea-formaldehyde were inferior to those produced with urea-formaldehyde. Values of water absorption after 2 hours of water immersion were close to those reported by Barros Filho et al. ${ }^{9}$ for similar particleboards produced with industrial sugarcane bagasse. However, those authors found higher water absorption after 24 hours of immersion and higher thickness swelling after 2 and 24 hours of water immersion (WA_2h $=6.7 \%$; WA_24h $=91.2 \%$; TS_2h $=7.2 \%$; TS_24h $=18.0 \%$ ).

No relation between $\mathrm{kg}$ and water absorption or thickness swelling after 2 hours and 24 hours of water immersion was observed (Figure 9). 1-layer particleboards produced with melamine-urea-formaldehyde, which had higher kg, did not present higher values of water absorption and thickness swelling. Melamine-urea-formaldehyde

○WA_2h - WA_24h

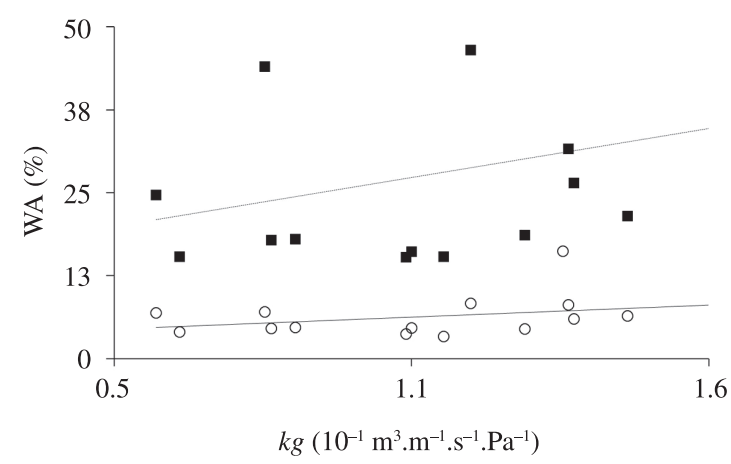

Figure 8. Superficial air permeability $(\mathrm{kg})$ vs. water absorption (WA) after 2 hours and 24 hours for melamine-urea-formaldehyde particleboards.

oTS_2h - TS_24h

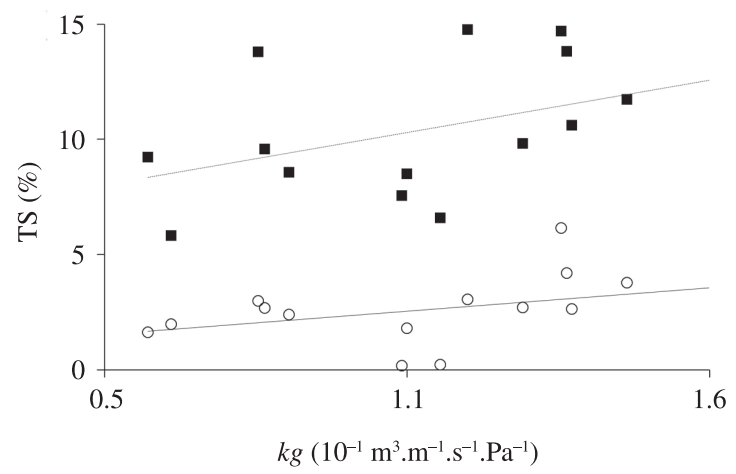

Figure 9. Superficial air permeability $(\mathrm{kg}) \mathrm{vs}$. thickness swelling (TS) after 2 hours and 24 hours for melamine-urea-formaldehyde particleboards. 
Table 2. Physical properties of 3-layer particleboards produced with two adhesives mixtures and commercial particleboards.

\begin{tabular}{ccccc}
\hline \multirow{2}{*}{ Particleboard } & \multicolumn{2}{c}{ Water absorption } & \multicolumn{2}{c}{ Thickness swelling } \\
\cline { 2 - 5 } & 2 hours $(\%)$ & 24 hours $(\%)$ & 2 hours $(\%)$ & 24 hours $(\%)$ \\
\hline MUF/UF9-3L & $15^{(6.48)}$ & $64^{(15.25)}$ & $8.5^{(2.77)}$ & $24.2^{(4.36)}$ \\
UF/MUF9-3L & $9^{(5.38)}$ & $35^{(15.70)}$ & $4.2^{(1.39)}$ & $15.6^{(2.95)}$ \\
Commercial & $9^{(0.24)}$ & $34^{(12.97)}$ & $2.6^{(0.64)}$ & $11.5^{(2.18)}$ \\
\hline
\end{tabular}

Standard deviation (\%) between parentheses.

presents higher resistance to higher moisture contents than urea-formaldehyde31.Therefore, the adhesive's content and position in the mat were the main factors that affected the ease at which the particleboard absorbs fluids.

The physical properties of MUF/UF particleboards are presented in Table 2. Despite the higher moisture-resistance of melamine-urea-formaldehyde (MUF) adhesive and its position in the surface of panels, the MUF/UF9-3L particleboards presented higher values of thickness swelling and water absorption than UF/MUF9-3L particleboards. It is important to mention that MUF/UF9-3L particleboards presented the highest air permeability values among all particleboards studied. Therefore, in this case, a clear relation between high permeability and higher values for physical properties was observed.

The values of thickness swelling after 24 hours were compared with the values recommended by the EN $312-3^{32}$ standard for use in humid conditions (Type P3). The standard establishes that the thickness swelling after 24 hours must be lower than $14 \%$ for non load-bearing boards. Therefore, the use of both urea-formaldehyde and melamine-urea-formaldehyde in the composition of sugarcane particleboards is not recommended. 1-layer and 3-layer particleboards made with urea-formaldehyde at $9 \%$ in the surface and core layers (UF9-1L and UF9-3L) were not suitable.

Finally, most of the laboratorial particleboards presented higher water absorption and thickness swelling than commercial particleboards. In general UF9-1L and MUF/UF9-3L particleboards presented the highest $\mathrm{kg}$ values and less appropriate physical properties.

\section{Conclusions}

Studies concerning the analysis of physical and mechanical properties of sugarcane particleboards are common in the literature, but there is a lack of information about their microstructure. The air permeability is a physical property of extreme importance to the development of durable fibrous cellulosic products and it strongly depends on their microstructure. The influences of mat type and adhesive type, position and content on superficial air permeability $(\mathrm{kg})$, Darcian constant $\left(k_{1}\right)$ and non-Darcian constant $\left(k_{2}\right)$ were investigated for sugarcane particleboards. $\mathrm{kg}$ was related to $k 1, k 2$, and water sorption resistance of the particleboards. The following conclusions were obtained:
- 1-layer particleboards presented higher superficial air permeability $(\mathrm{kg})$ than 3-layer particleboards, which surface is made of smaller particles;

- In general, type, position and content of adhesives did not influence superficial air permeability $(\mathrm{kg})$ of particleboards. However, these processing variables caused impact on the interactions between fluid and porous media and on the tortuosity of the porous media $\left(k_{1}\right.$ and $\left.k_{2}\right)$;

- No relation between sorption characteristics and superficial air permeability $(\mathrm{kg})$ after 2 hours of water immersion for particleboards produced with urea-formaldehyde was detected. However, after 24 hours water immersion, particleboard swelling and absorption increased as air permeability increased. Such relations were not observed for particleboards produced with melamine-urea-formaldehyde; and

- Under physical tests, most of the panel compositions used complied with the European Committee for non load-bearing boards, while the use of both urea-formaldehyde and melamine-urea-formaldehyde in 3-layer mats is not recommended for sugar cane particleboard production due to the high $\mathrm{kg}$ values and water uptake observed.

Further studies are needed in order to establish a relation between the permeability and some measurable geometric quantities (e.g., porosity, tortuosity, pore size distribution, connectivity and specific surface). X-ray tomography and morphological 3D image may be useful tools for such characterizations. Regarding water resistance, the information provided in this work shows that industry should produce sugarcane bagasse particleboards with low air permeability. However, future investigations must be carried out to verify the influence of air permeability on packaging quality of particleboards, as well as on their thermal and acoustic insulation.

\section{Acknowledgements}

Financial support for this research was provided by "Fundação de Amparo à Pesquisa do Estado de Minas Gerais" - FAPEMIG, "Coordenação de Aperfeiçoamento de Pessoal de Nível Superior" - CAPES, and "Conselho Nacional de Desenvolvimento Científico e Tecnológico" - CNPq, in Brazil. 


\section{References}

1. Mohebby B, Gorbani-kokandesh M and Soltani M. Springback in acetylated wood based composites. Construction and Building Materials. 2009; 23(9):3103-3106. http://dx.doi. org/10.1016/j.conbuildmat.2009.02.007

2. Buyuksari U, Ayrilmis N, Avci E and Koc E. Evaluation of the physical, mechanical properties and formaldehyde emission of particleboard manufactured from waste stone pine (Pinus pinea L.) cones. Bioresource Technology. 2010; 101(1):255-259. PMid:19733063. http://dx.doi.org/10.1016/j. biortech.2009.08.038

3. Zheng Y, Pan Z, Zhang R, Jenkings BM and Blunk S. Particleboard quality characteristics of saline jose tall wheatgrass and chemical treatment effect. Bioresource Technology. 2007; 98(6):1304-1310. PMid:16806907. http:// dx.doi.org/10.1016/j.biortech.2006.04.036

4. Guntekin E and Karakus B. Feasibility of using eggplant (Solanum melongena) stalks in the production of experimental particleboard. Industrial Crops and Products. 2008; 27(3):354-358. http://dx.doi.org/10.1016/j. indcrop.2007.12.003

5. Widyorini R, Xu J, Umemura K and Kawai S. Manufacture and properties of binderless particleboard from bagasse I. Part 2: effects of raw material type, storage methods, and manufacturing process. Journal of Wood Science. 2005; 51(6):648-654. http:// dx.doi.org/10.1007/s10086-005-0713-Z

6. Xu X, Yao F, Wu Q and Zhou D. The influence of wax-sizing on dimension stability and mechanical properties of bagasse particleboard. Industrial Crops and Products. 2009; 29(1):80-85. http://dx.doi.org/10.1016/j. indcrop.2008.04.008

7. Rowell RM and Keany FM. Fiberboards made from acetylated bagasse fiber. Wood and Fiber Science. 1991; 23(1):15-22.

8. Pandey A, Soccol CR, Nigam P and Soccol VT. Biotechnological potential of agro-industrial residues. I: sugarcane Bagasse. Bioresource Technology. 2000; 74(1):69-80. http://dx.doi. org/10.1016/S0960-8524(99)00142-X

9. Barros Filho RM, Mendes LM, Novack KM, Aprelini LO and Botaro VR. Hybrid chipboard panels based on sugarcane bagasse, urea formaldehyde and melamine formaldehyde resin. Industrial Crops and Products. 2011; 33(2):369-373. http:// dx.doi.org/10.1016/j.indcrop.2010.11.007

10. Houreau W, Oliveira FB, Grelier S, Siegmund B, Frollini E and Castellan A. Fiberboards Based on Sugarcane Bagasse Lignin and Fibers. Journal of Applied Polymer Science. 2006; 291(7):829-839.

11. Mendes RF, Mendes LM, Guimarães Júnior JB, Santos RC and Bufalino L. The adhesive effect on the properties of particleboards made from sugar cane bagasse generated in the distiller. Revista Ciências Agrárias. 2009; 32(2):209-218

12. Tabarsa T, Ashori A and Gholamzadeh M. Evaluation of surface roughness and mechanical properties of particleboard panels made from bagasse. Composites Part $B$ : Engineering. 2011; 42(5):1330-1335. http://dx.doi. org/10.1016/j.compositesb.2010.12.018

13. Hartley ID, Wang S and Zhang Y. Water vapor sorption isotherm modeling of commercial oriented strand panel based on species groups and resin type. Building and Environment. 2007; 42(10):3655-3659. http://dx.doi. org/10.1016/j.buildenv.2006.10.002

14. Siau JF. Flow in Wood. Syracuse: Syracuse University; 1971. PMid:5281978.

15. Tonoli GHD, Santos SF, Joaquim AP and Savastano Junior H. Effect of accelerated carbonation on cementitious roofing tiles reinforced with lignocellulosic fibre. Construction and Building Materials. 2010; 24(2):193-201. http://dx.doi.org/10.1016/j. conbuildmat.2007.11.018

16. Deliseé C, Lux J and Malvestio J. 3D Morphology and permeability of highly porous cellulosic fibrous material. Transport in Porous Media. 2010; 83:623-636. http://dx.doi. org/10.1007/s11242-009-9464-4

17. Hata T. Heat flow in particle mat and properties of particleboard under steam injection pressing. Wood Research. 1993; 80:1-47.

18. Garcia RA and Cloutier A. Characterization of heat and mass transfer in the mat during hot pressing of MDF panels. Wood and Fiber Science. 2005; 37(1):23-41.

19. Fakhri HR, Semple KE and Smith GD. Permeability of OSB. Part I. the effects of core fines content and mat density on transverse permeability. Wood and Fiber Science. 2006; 38(3):540-462.

20. Dai $\mathrm{C}, \mathrm{Yu} \mathrm{C}$, Zhou X. Heat and mass transfer in wood composite panels during hot pressing. Part II. Modeling Void Formation and Mat Permeability. Wood and Fiber Science. 2005; 37(2):242-257.

21. Silva MR, Machado GO, Deiner J and Calil Junior C. Permeability measurements of Brazilian Eucalyptus. Materials Research. 2010; 13:281-286. http://dx.doi.org/10.1590/ S1516-14392010000300002

22. Salomão R, Cardoso FA, Innocentini MDM, Bittencourt LRM and Pandolfelli VC. Polymeric fibers and the permeability of refractory castables. Cerâmica. 2003; 49(3):23-8.

23. Innocentini MDM, PardoARF, Menegazzo BA, Bittencourt LRM, Rettore RP and Pandolfelli VC. Permeability of high-alumina refractory castables based on various hydraulic binders. Journal of American Ceramic Society. 2002; 85(6):1517-21. http:// dx.doi.org/10.1111/j.1151-2916.2002.tb00306.x

24. American Society For Testing Materials - ASTM. ASTM D 1037: Standard methods of evaluating the properties of wood-base fiber and particle panel materials. Philadelphia: ASTM; 1999.

25. Hood JP, Kamke FA and Fuller J. Permeability of oriented strand boards mats. Forest Products Journal. 2005; 55(12):194-199.

26. Shang DK, Yan QY, Tan HP and Sun BH. The experimental research and analysis of permeability of basalt and wood particle aggregates. Holz als Roh- und Werkstoff. 1999; 57(3):271-275. http://dx.doi.org/10.1007/s001070050057

27. Zheng Y, Pan Z, Zhang R, Jenkins BM and Sherry B. Properties of medium-density particleboard from saline Athel wood. Industrial Crops and Products. 2006; 23:318-326. http://dx.doi. org/10.1016/j.indcrop.2005.09.003

28. Geimer RL. Weathering characteristics of particleboard. USDA Forest Service; 1973. Research paper FPL-212.

29. Li X, Cai Z, Winandy JE and Basta AH. Selected properties of particleboard panels manufactured from rice straws of different geometries. Bioresource Technology. 2010; 101(12):4662-4666. PMid:20153181. http:// dx.doi.org/10.1016/j.biortech.2010.01.053

30. Pan Z, Zheng Y, Zhang R and Jenkins BM. Physical properties of thin particleboard made from saline eucalyptus. Industrial Crops and Products. 2007; 26(3):185-194. http://dx.doi. org/10.1016/j.indcrop.2007.03.006

31. Pizzi A and Mittal KL. Handbook of adhesive technology. New York: Marcel Dekker; 1994

32. European Committee for Standardization - ECS. EN 312-3: Particleboards. Specifications. Requirements for boards for interior fitments (including furniture) for use in dry conditions. Geneva: ECS; 1993. 